\title{
Dynamic Response of Vertical Irregular Building As Per IS 1893(Part 1):2016
}

\author{
Krishna Prasad Bhatta, Gurpreet Singh
}

\begin{abstract}
Nowadays highly increases in the high rise building with architectural requirement in modern city. The purpose of the study is to understand the response of the building due to vertical irregularities. In this paper the incorporated irregularities are as per IS1893 (Part)1:2016 and study response of 12 story building frame 13 models with mass irregular, stiffness irregular and vertical geometric irregularities are analyze in ETABS 2017 by linear dynamic analysis i.e. Response spectrum Analysis. The various structural response parameters such as maximum storey displacement, inter story drift and storey shear are taken to compare the result. Mass irregularity is placed in fourth story, stiffness irregularity is provided in first storey and vertical geometric irregularity is provided in different upper floor. It is concluded that the soft story at bottom highly increases the lateral displacement of that floor, mass irregular at fourth story highly increases the storey shear below that storey and vertical geometric irregularity effect on the relative displacement of building. Combined irregularity highly effect performance of the building therefore chance of collapse also increases as increases in irregularities. All the comparison are represented graphically.

Keywords: Response Spectrum Method, ETABS, Mass irregular, Soft Story, Vertical Geometric Irregularity.
\end{abstract}

\section{INTRODUCTION}

Today's irregularity in building is most common in high rise building construction. There are two different types of plane and vertical irregularity provided in building. Irregularity in building tends to collapse during earthquake. Damage in RC building during Bhuj earthquake in India killed huge life mostly due to provided irregularities in structure. Irregularity in building cause non uniform load distribution in member of a building. Several studies has been done on the irregularities, viz., Dynamic seismic evaluation of irregular multistory building with bracing and heavy mass placed at $6^{\text {th }}$ and $9^{\text {th }}$ floor using response spectrum method(Sharma and Nasier, 2019), Analysis of irregular structure under earthquake load (Abraham, N.M. and SD, A.K., 2019), Critical analysis of building with vertical irregularities as per IS 1893 Part-1:2002 ( Shah and shrivastava,2018), Response of structurally irregular building frame using equivalent static method (Dhiman et al., 2012)etc. in this present paper response of 12-storeyed plane frame to lateral load is studied for mass, stiffness and vertical geometrical irregularities in the evaluation .

Revised Manuscript Received on February 28, 2020.

* Correspondence Author

Krishna Prasad Bhatta*, M.E. Structure , Civil Engineering Department, Chandigarh University, Gharuan, Mohali, Punjab, India.

Gurpreet Singh, Assistance Professor Civil Engineering Department, Chandigarh University, Gharuan, Mohali, Punjab, India.

(C) The Authors. Published by Blue Eyes Intelligence Engineering and Sciences Publication (BEIESP). This is an open access article under the CC-BY-NC-ND license http://creativecommons.org/licenses/by-nc-nd/4.0/

\section{Types of vertical irregularities in building}

Basically, vertical irregularity in building as per IS 1893 part-1:2016 can be classified as-

- Stiffness Irregularity- Stiffness irregularity is a storey whose lateral stiffness is less than that of storey above.

- Mass Irregularity- It is considered when the seismic weight of any floor is more than 150 percent of that of floor below.

- Vertical Geometric Irregularity- It shall be considered when the horizontal dimension of the lateral force resisting system in any storey is more than 125 percent of the storey below.

\section{OBJECTIVE OF THE STUDY}

- The main Objective of this research is to study the dynamic response of vertical irregular building using Etabs software as per IS 1893 (Part 1):2016.

- To study the response of regular square shape building and $\mathrm{H}$ shape building with incorporated vertical irregularity.

- To find the structural parameter such as story displacement, story shears and inter story drift and compared the result.

\section{METHODOLOGY}

In this research work, thirteen models are prepared. These models are divided into three cases. In case1 (five models) in which vertical irregularities was incorporated in $\mathrm{H}$ shape models. In case2 (five models) in which vertical irregularities incorporated in setback provided in two floor building. In case3 (five models) in which vertical irregularities incorporated in setback provided in three floor building. All the models were analyzed by linear dynamic analysis i.e. Response Spectrum method using Etabs software. Story displacement, inter story drift and story shear are the parameters used to compared the result. All the models were compared with regular square shape building. All the building frames Special RC moment resisting frame fixed at base.

Model Description

Table-I: Model Description

\begin{tabular}{|l|c|}
\hline \multicolumn{1}{|c|}{ Model description } & Value \\
\hline Plan & $45 \times 45$ \\
\hline No. of bay along in X direction & 9 \\
\hline No. of bay along in Y direction & 9 \\
\hline Bay length in X direction & 5 \\
\hline Bay length in Y direction & 5 \\
\hline Story Height & 3.5 \\
\hline No. of story & 12 \\
\hline
\end{tabular}




\section{Section Properties}

Table-II: Section Properties

\begin{tabular}{|l|c|}
\hline \multicolumn{1}{|c|}{ Section Properties } & Value \\
\hline Slab Section & $200 \mathrm{~mm}$ \\
\hline Column (up to 6 stories) & $600 \mathrm{~mm} \times 600 \mathrm{~mm}$ \\
\hline Column (above 6 stories) & $450 \mathrm{~mm} \times 450 \mathrm{~mm}$ \\
\hline Beam & $500 \mathrm{~mm} \times 300 \mathrm{~mm}$ \\
\hline
\end{tabular}

\section{Gravity Loading}

Table-III: Gravity Loading

\begin{tabular}{|l|c|}
\hline \multicolumn{1}{|c|}{ Gravity Load } & Value \\
\hline Floor finish & $1.5 \mathrm{KN} / \mathrm{m}^{2}$ \\
\hline Live load & $3 \mathrm{KN} / \mathrm{m}^{2}$ \\
\hline Live load on Roof & $1.5 \mathrm{KN} / \mathrm{m}^{2}$ \\
\hline
\end{tabular}

\section{Material Properties}

Table- IV: Material Properties

\begin{tabular}{|l|c|}
\hline Material Properties & Value \\
\hline Density of concrete & $25 \mathrm{KN} / \mathrm{m}^{3}$ \\
\hline Grade of concrete & M30 \\
\hline Grade of Rebar & HYSD500 \\
\hline
\end{tabular}

\section{Seismic Load}

Table-V: Seismic Load

\begin{tabular}{|l|c|}
\hline Seismic load & Value \\
\hline Importance Factor, I & 1.2 \\
\hline Location of building & Zone-IV \\
\hline Type of soil & Type-II \\
\hline Damping of structure & 5 percent \\
\hline Response Reduction factor & 5 \\
\hline
\end{tabular}

\section{Regular Square Shape Building}
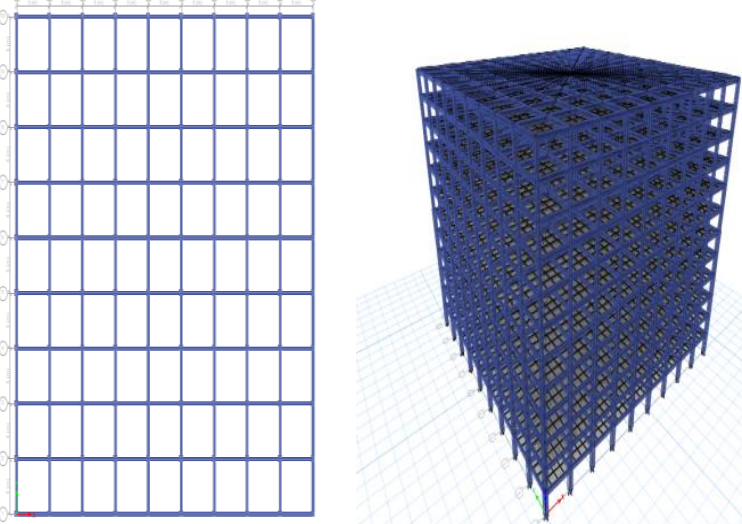

Fig 1: plan and 3D View of regular square shape structure

H shape Building
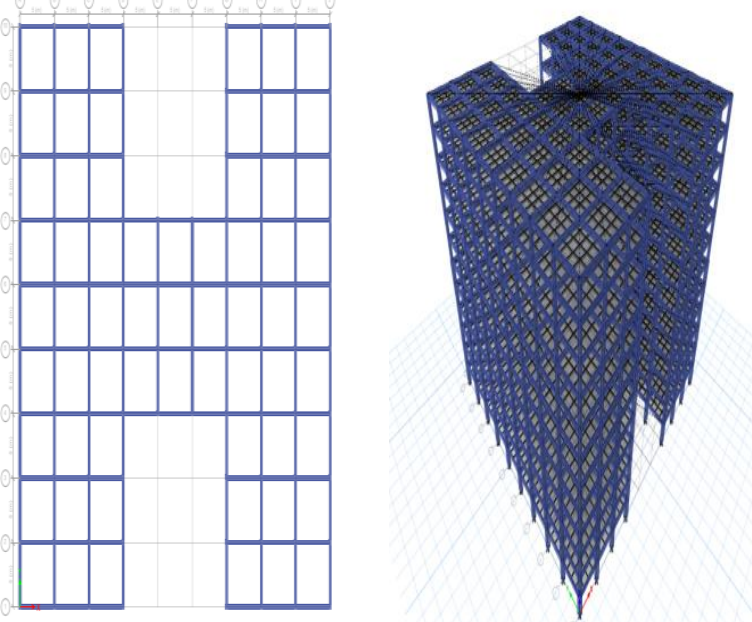

Fig 2: plan and 3D View of $H$ shape building

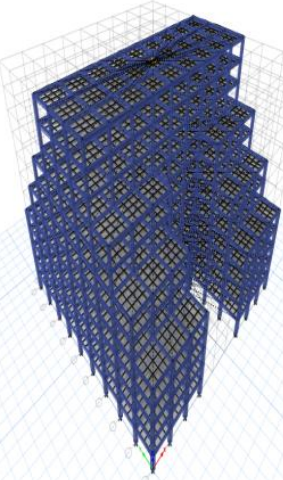

Fig 4: Side elevation of $\mathrm{H}$ shape building with setback at three floors

Table-VI: Three Different Cases

\begin{tabular}{|c|c|c|}
\hline S.N. & Model description & Denotation \\
\hline \multirow{5}{*}{ Case 1} & Regular Square shape building & M1 \\
\hline & H shape regular building & M2 \\
\hline & $\begin{array}{l}\text { Stiffness irregular provided in ground } \\
\text { story at model M2 }\end{array}$ & M5 \\
\hline & $\begin{array}{l}\text { Mass irregular provided in fourth floor } \\
\text { at model M2. }\end{array}$ & M8 \\
\hline & $\begin{array}{l}\text { Combined of Stiffness and Mass } \\
\text { irregularity at M2 }\end{array}$ & M11 \\
\hline \multirow{5}{*}{ Case 2} & Regular Square shape building & M1 \\
\hline & $\begin{array}{l}\text { Vertical geometric irregular setback } \\
\text { provided in } \mathrm{H} \text { shape model at two } \\
\text { floors }\end{array}$ & M4 \\
\hline & $\begin{array}{l}\text { Stiffness irregular provided in ground } \\
\text { story at model M4 }\end{array}$ & M7 \\
\hline & $\begin{array}{l}\text { Mass irregular provided in fourth floor } \\
\text { at model M4 }\end{array}$ & M10 \\
\hline & $\begin{array}{l}\text { Combined of Stiffness and Mass } \\
\text { irregularity M4 }\end{array}$ & M13 \\
\hline \multirow{5}{*}{ Case 3} & Regular Square shape building & M1 \\
\hline & $\begin{array}{l}\text { Vertical geometric irregular setback } \\
\text { provided in } \mathrm{H} \text { shape model at three } \\
\text { floors }\end{array}$ & M3 \\
\hline & $\begin{array}{l}\text { Stiffness irregular provided in ground } \\
\text { story at model M3 }\end{array}$ & M6 \\
\hline & $\begin{array}{l}\text { Mass irregular provided in fourth floor } \\
\text { at model M3 }\end{array}$ & M9 \\
\hline & $\begin{array}{l}\text { Combined of Stiffness and Mass } \\
\text { irregularity M3 }\end{array}$ & M12 \\
\hline
\end{tabular}

Fig 3: side elevation of $\mathbf{H}$ shape with setback at two floors floor
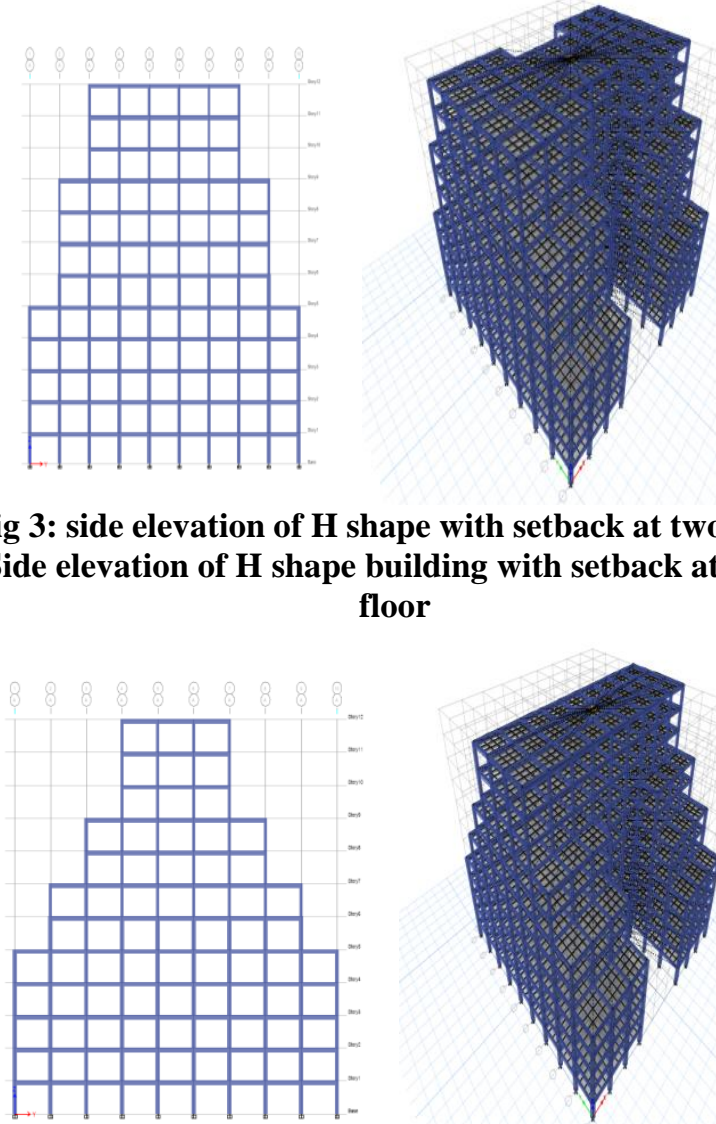

Side elevation of $\mathbf{H}$ shape building with setback at three 
Mass irregular Structure- Heavy mass load $20 \mathrm{KN} / \mathrm{m}^{2}$ was placed at fourth floor for mass irregularity. Heavy mass floor is made for storage heavy equipment. Seismic weight of this story is more than 150 percent than floor above and below due to this heavy load creates mass irregularity in building.

Stiffness Irregular Structure- We know that lateral stiffness is inversely proportional to height of story. First story height increase to $5 \mathrm{~m}$ due to this lateral stiffness of the story is less than that of story above (i.e. soft story in the first story of building). Height of story is increase for parking purpose.

Vertical Geometric Irregular Structure-Setback is provided in 5th floor and 9th floor in case $2 \mathrm{H}$ shape model. In case 3 setback is provided in 5th, 7th and 9th floor by maintaining setback didn't create mass irregularity in consecutive floor.

Response Spectrum Method -analysis was carried out using Etabs 2016 as per IS 1893(Part-1):2016. In this method mass participation ratio maintains greater than 90 percent.

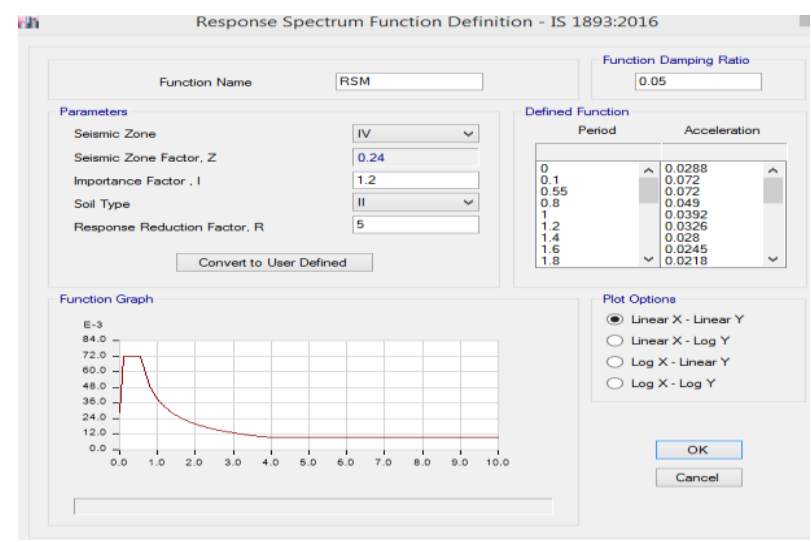

Fig 5: Response Spectrum function definition as IS

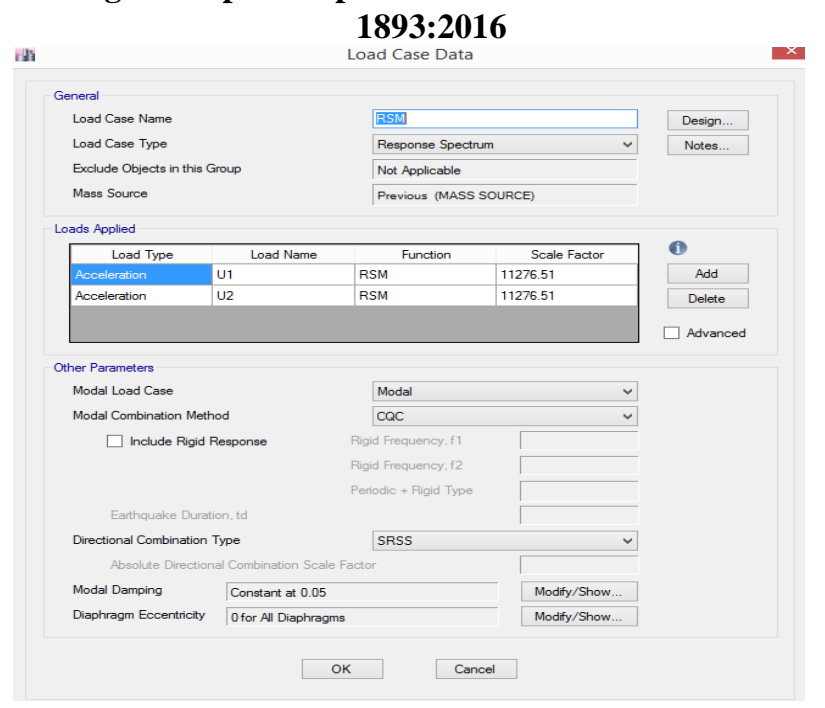

Fig 6: Response Spectrum function load case data

\section{RESULT AND DISCUSSION}

The result extracted from the ETABS was represented in graph and chart, and then they were studied very carefully. Case 1-Comparison of regular square shape frame model with $\mathbf{H}$ shape model providing mass irregular, soft story and combined mass and soft story vertical irregularities.

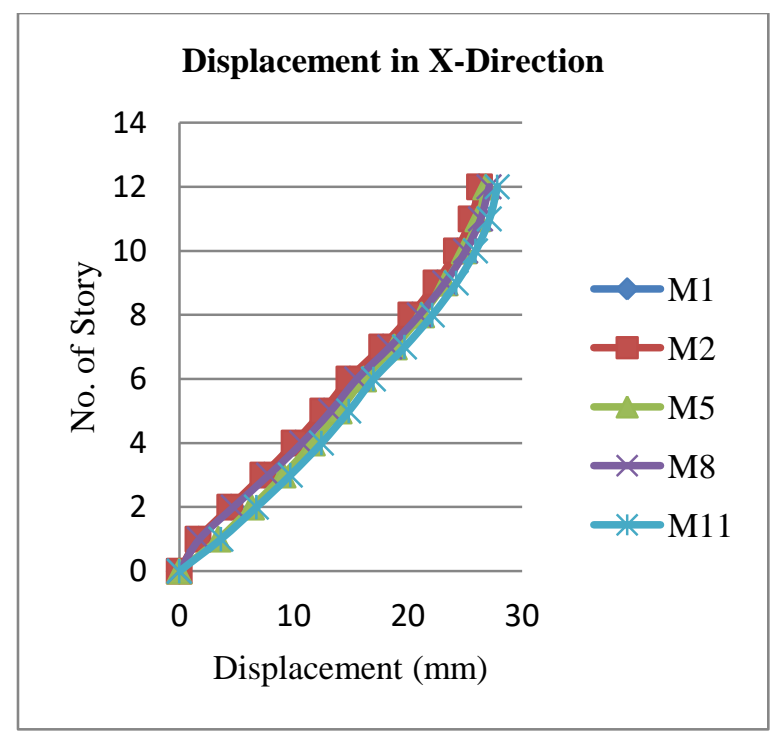

Fig 7: Displacement in $\mathrm{X}$ direction

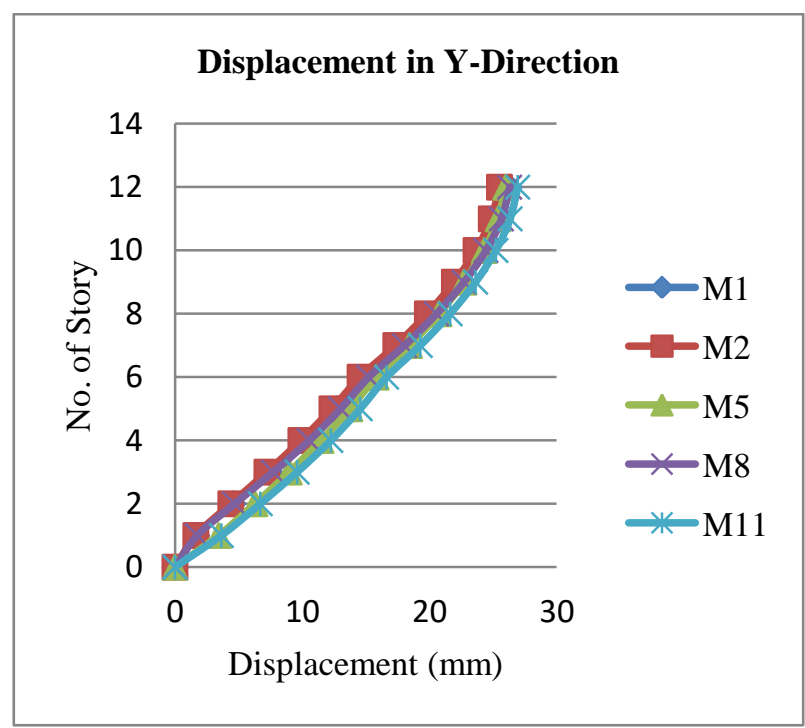

Fig 8: Displacement in Y direction

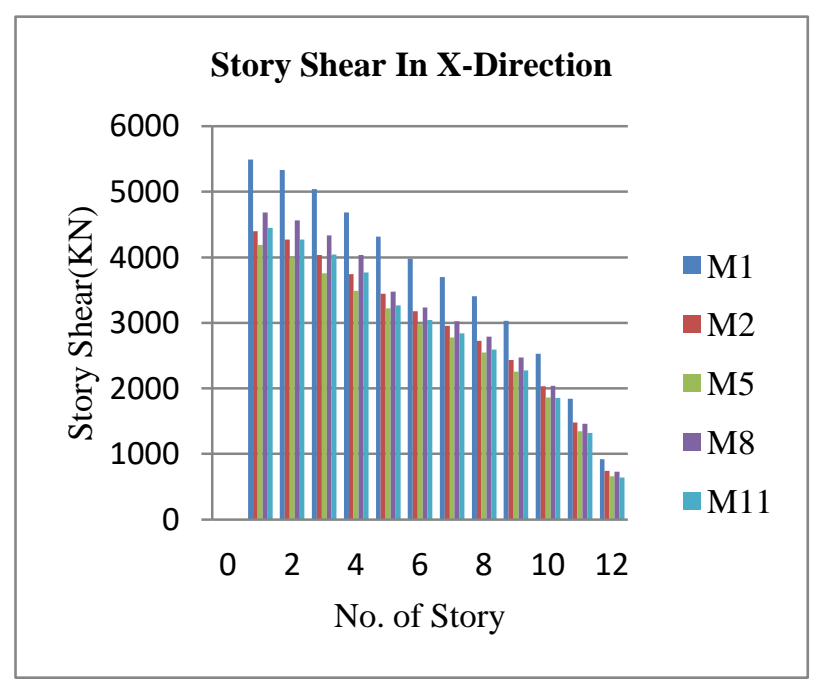

Fig 9: Story Shear in X Direction 


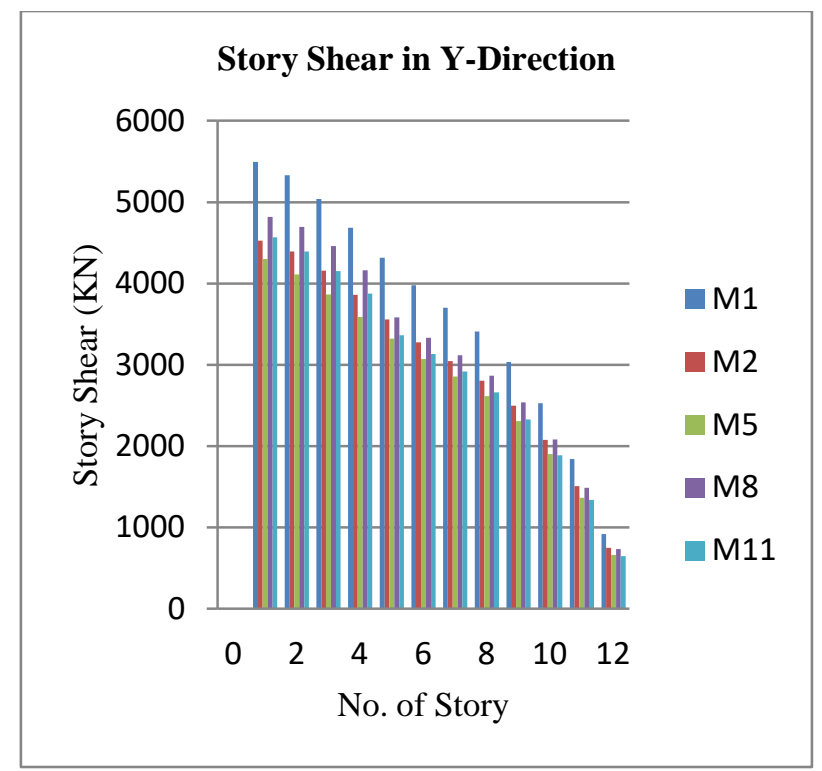

Fig 10: Story Shear in Y Direction

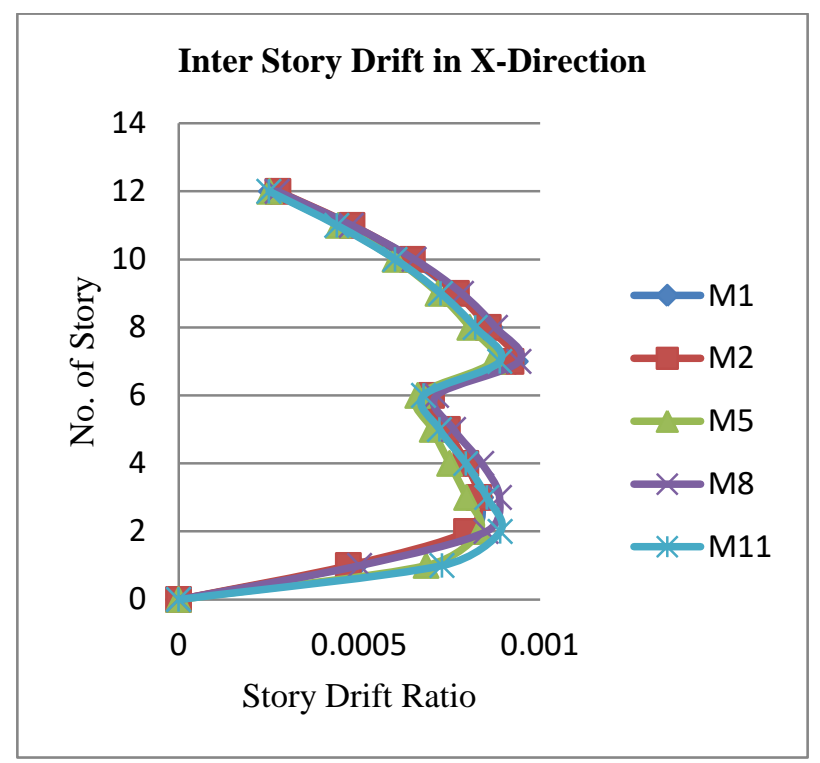

Fig 11: Inter Story Drift in X Direction

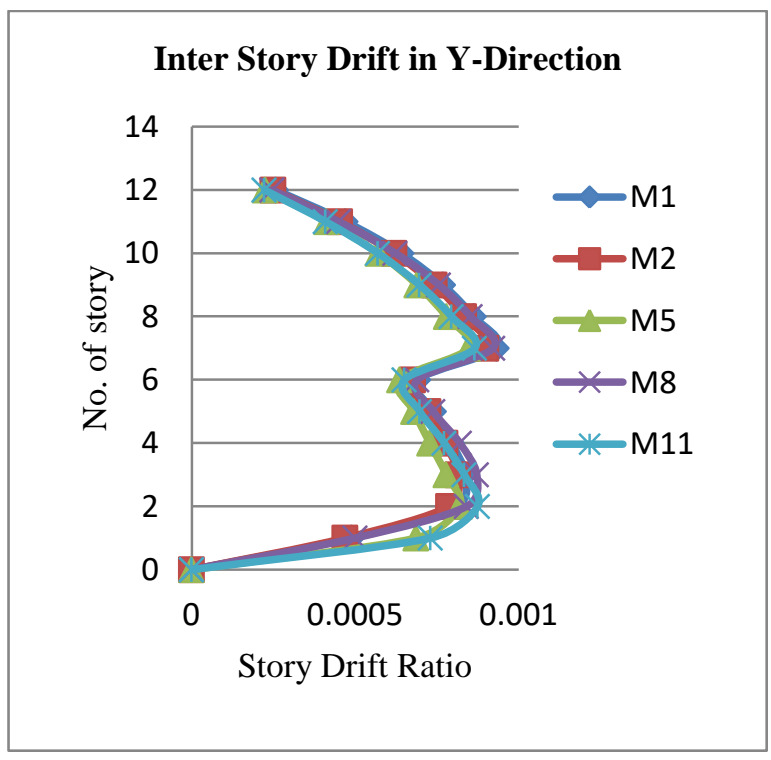

Fig 12: Inter story Drift in Y-Direction
Case 2 Comparison of regular square shape model with $\mathbf{H}$ shape setback model (setback at two floors) providing mass irregular, soft story and combined mass and soft story vertical irregularities.

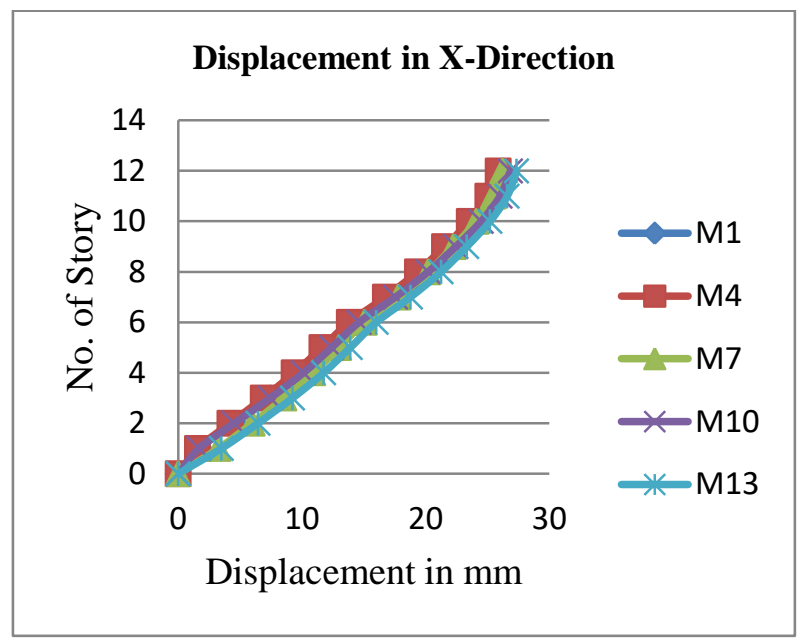

Fig 13: Displacement in $\mathrm{X}$ direction

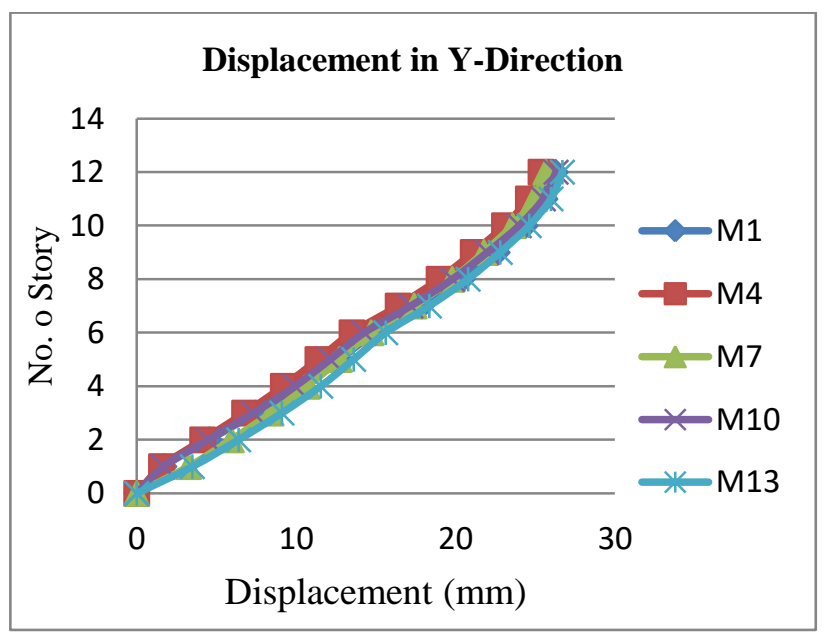

Fig 14: Displacement in Y direction

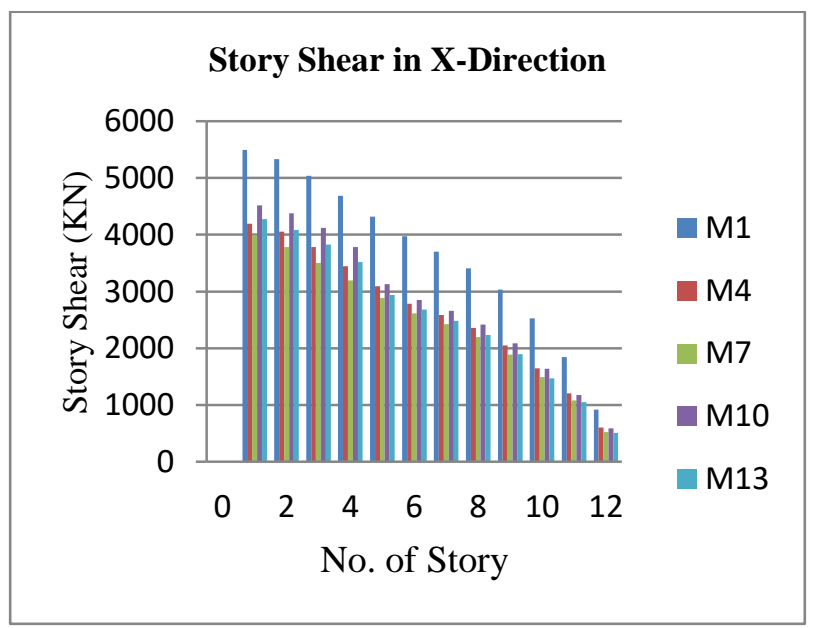

Fig 15: Story Shear in X Direction

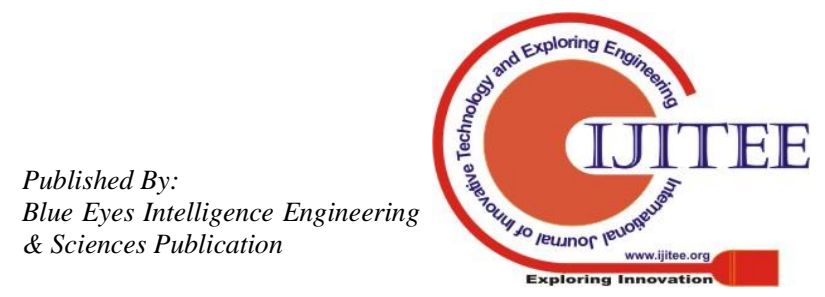




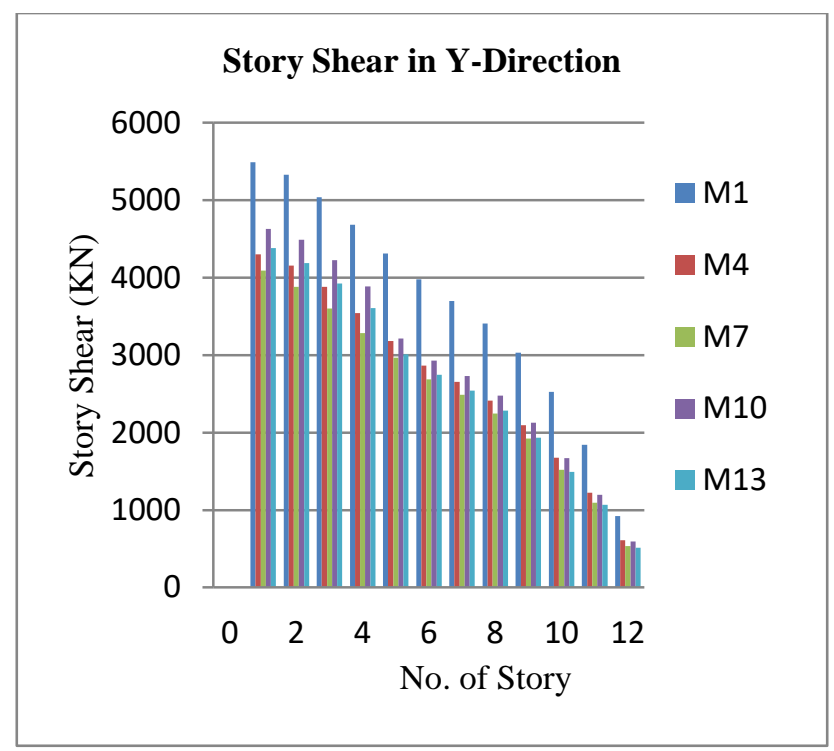

Fig 16: Story Shear in Y Direction

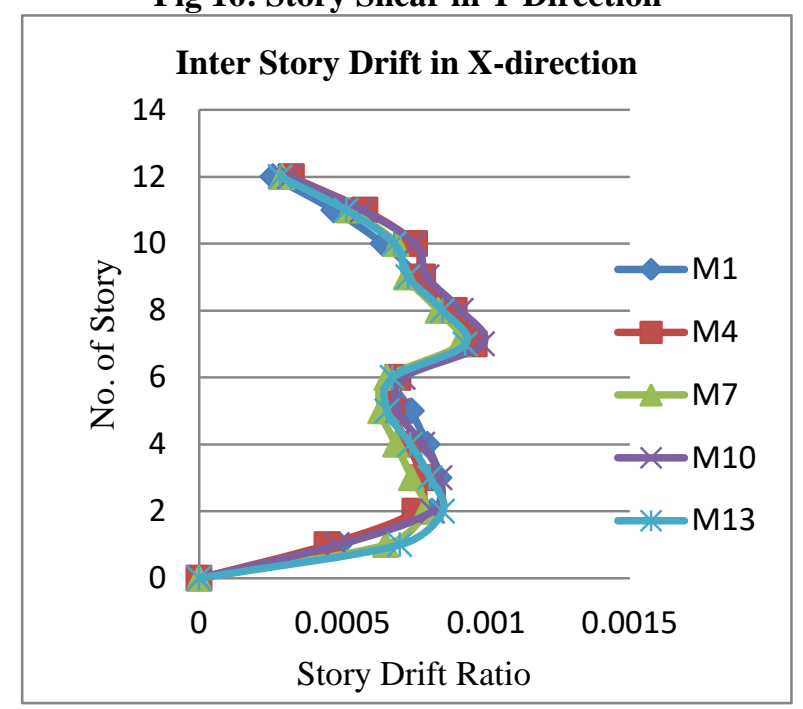

Fig 17: Inter story Drift in X Direction

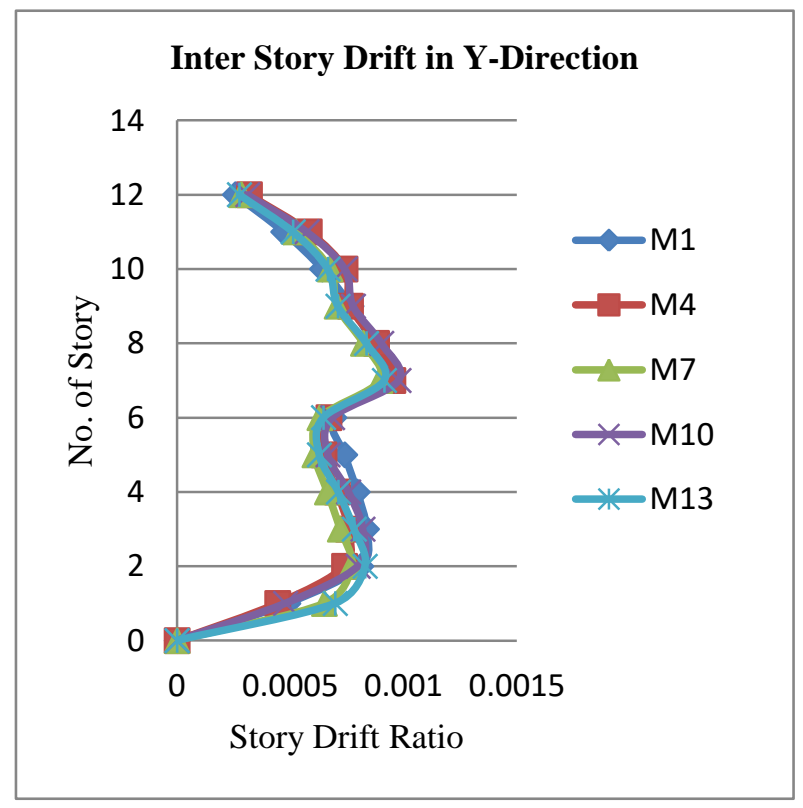

Fig 18: Inter story Drift in $X$ Direction

Case 3 Comparison of regular square shape model with $H$ shape setback model (setback at three floors) providing mass irregular, soft story and combined mass and soft story vertical irregularities.

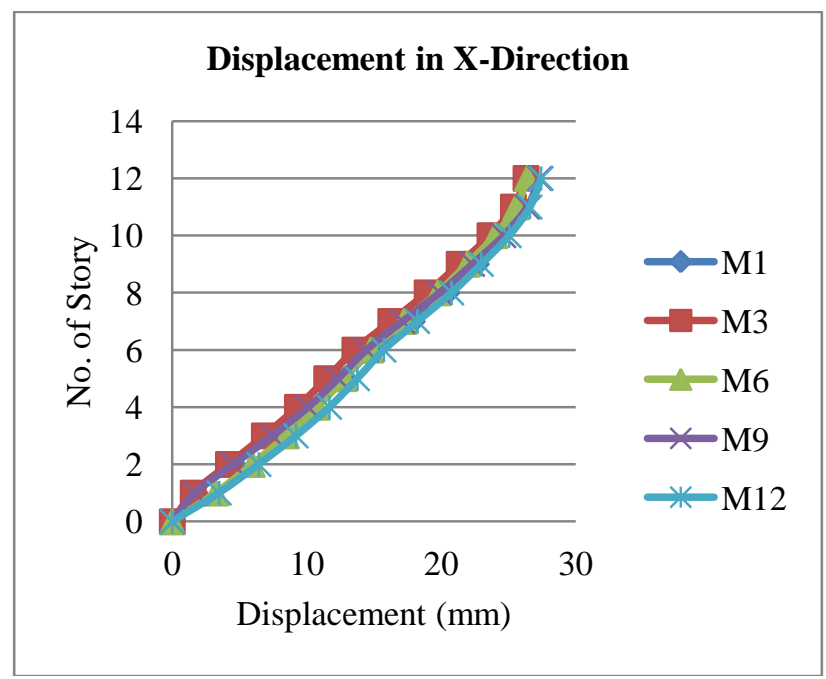

Fig 19: Inter story Drift in X Direction

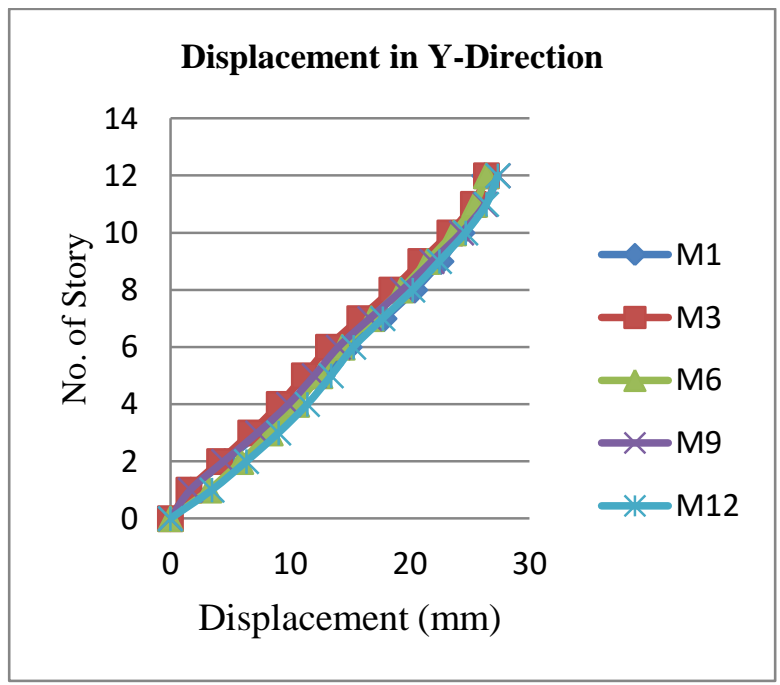

Fig 20: Displacement in Y direction

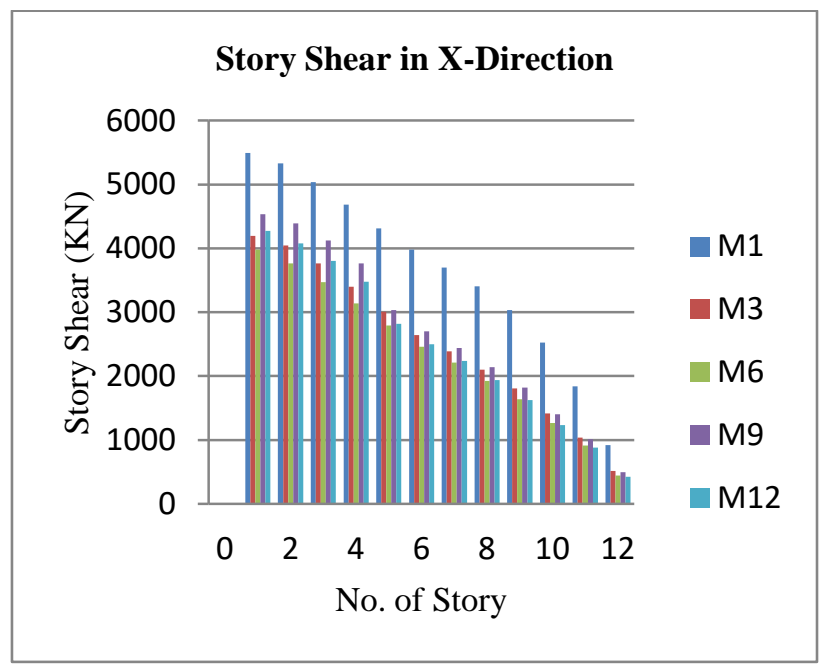

Fig 21: Story Shear in X Direction 


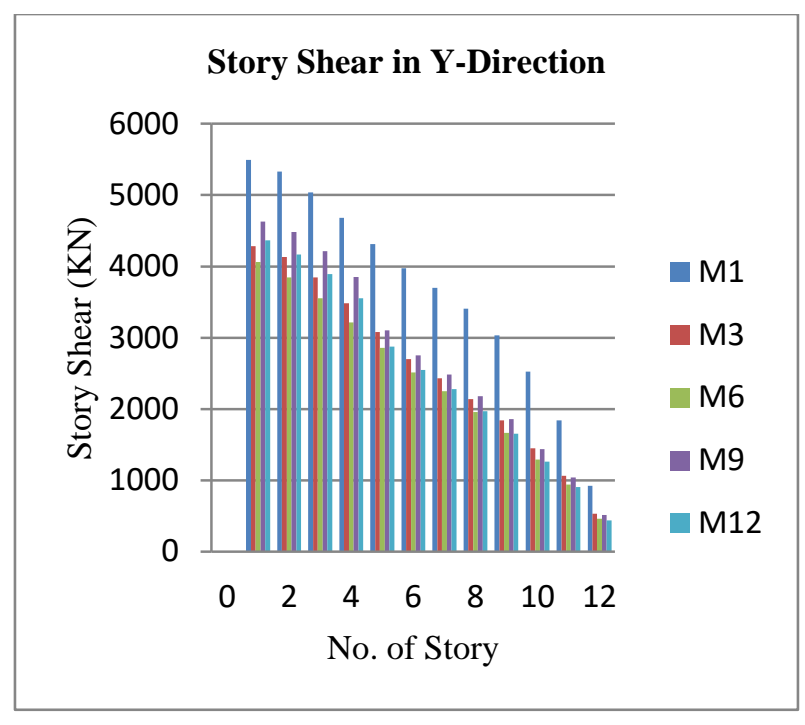

Fig 22: Story Shear in X Direction

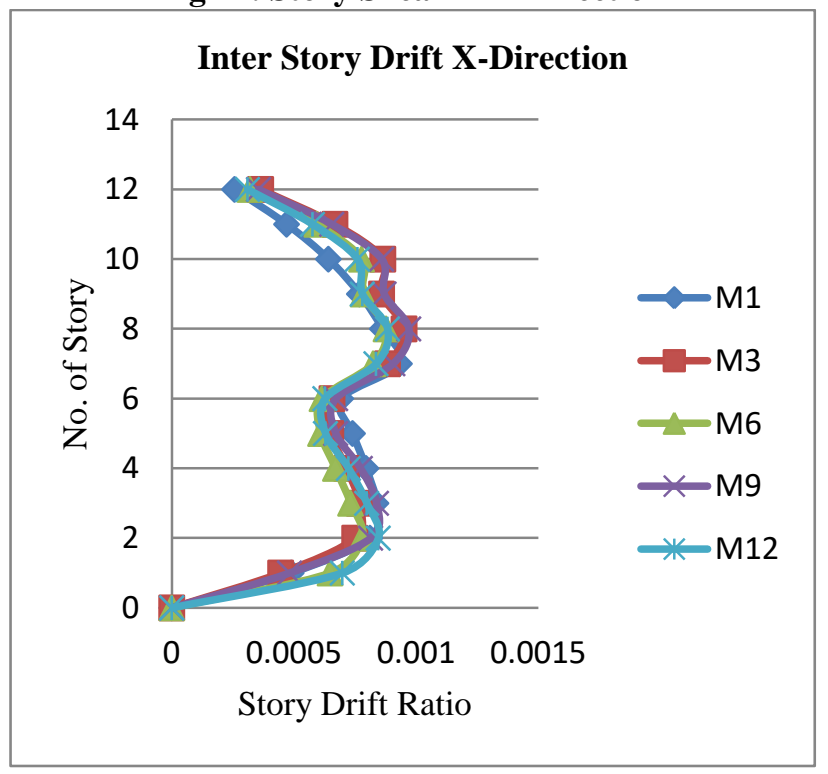

Fig 23: Inter story Drift in $X$ Direction

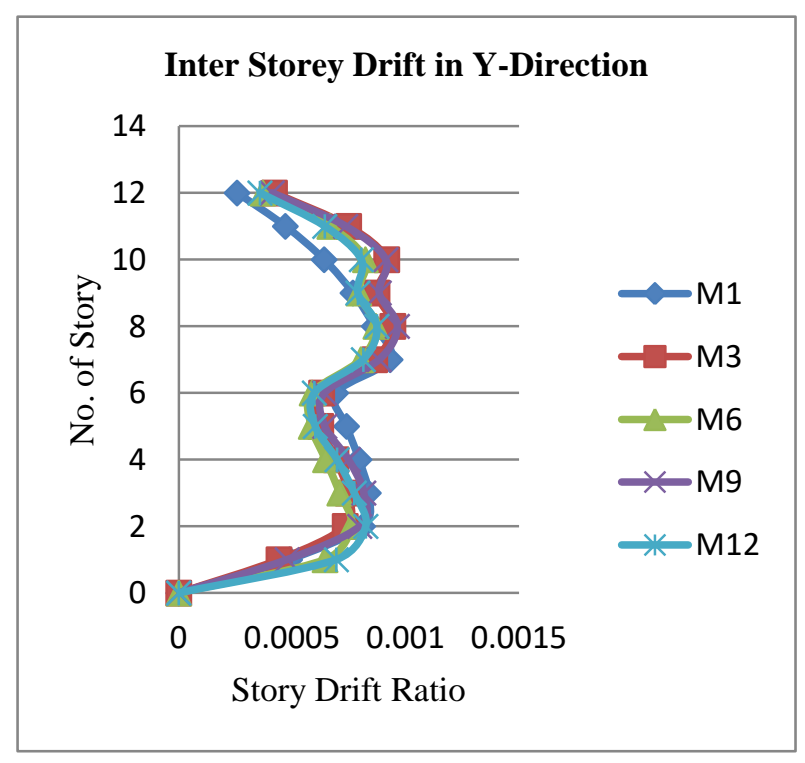

Fig 24: Inter story Drift in X Direction

\section{CONCLUSION}

This study was mainly focus on the response of vertical irregularities in building. Response spectrum analysis was conducted to gave clarity between these models by taking the results of maximum displacement, inter story drift and story shear to compared on these regular and irregular models. Final conclusion of the present research, which were drawn from result study, have been concluded in the following section:

- Top displacement of the regular square shape model shows less displacement than irregular models.

- As we increases the irregularity in the building displacement of the building also increases. Combined mass and stiffness irregularity models have high top displacement.

- $\quad$ M11 model H shape having combine mass and soft story shows the $27.84 \mathrm{~mm}$ maximum displacement at top.

- $\quad$ Stiffness irregularity i.e. soft story as base gives high lateral displacement at first story.

- Story shear was found increases from top to bottom. Regular cube shape high bottom story shear. Story shear was highly increases when mass irregularity provided.

- Minimum story shear was found 3976.975KN shown by irregular model M6. Combined effect of vertical geometric irregular and stiffness irregular gives the minimum story shear.

- As we increase the number of setback in the model its story shear goes decreasing.

- Inter story drift was found under the permissible limit $0.004 \mathrm{H}$. There was gradual change in the curve in regular building.

- In bottom story Inter story drift maximum in case of combined vertical irregularities models.

- As vertical geometric irregular i.e. setback provided inter story drift slope of curve was founded to drastic change. As increases setback in the building maximum inter story drift is shifted from lower story to upper story.

\section{REFERENCES}

1. Akhil R. and Kumar, A.S.,"Seismic analysis of regular and irregular buildings with vertical irregularity using staad. Pro," International Research Journal of Engineering and Technology (IRJET), Vol. 4, Issue 2, 2012, pp.1863-1866.

2. Joshi Divya and Santhi M.H., "Seismic Performance Evaluation of High Rise Building with Plan,” International Journal of Civil Engineering and Technology, Vol. 9, Issue 4, 2018, pp. 570-577.

3. Konakalla R., Chilakapati R.D. and Raparla D.H.B., "Response Study of Multi-Storied Buildings with Plan Irregularity Subjected To Earthquake and Wind Loads Using Linear Static Analysis," IOSR Journal of Mechanical and Civil Engineering, 2014, pp.2278-1684.

4. Sharma Lovneesh and Nasier Sandeep, "Dynamic Seismic Evaluation of Irregular Multistorey Building Using Bracing in Zone V as per IS: 1893-2016," International Journal of Innovative Technology and Exploring Engineering, Vol. 8, Issue 7, 2019, pp.1057-1062.

5. Poonam, A.K. and Gupta A.K., 2012, "Study of response of structurally irregular building frames to seismic excitations," International Journal of Civil, Structural, Environmental and Infrastructure Engineering Research and Development, Vol. 2, Issue2, 2012, pp. 25-31. 
6. Rahman, S.A.A.A. and Deshmukh G., "Seismic response of vertically irregular RC Frame with stiffness irregularity at fourth floor," International Journal of Emerging Technology and Advanced Engineering, Vol. 3, Issue 8, 2013, pp. 337-386.

7. Rahman, S.A.A.A. and Salik, A.U., "Seismic analysis of vertically irregular buildings," Current Science, Vol. 111, 2016, pp. 1658-1663.

8. Rana D. and Raheem, J., "Seismic Analysis of Regular \& Vertical Geometric Irregular RCC Framed Building," Int Res J Eng Technol, Vol. 2, Issue 4, 2015, pp.1396-1401.

9. Sameer J.S. and Shinde S.B., "Seismic response of vertically irregular rc frame with mass irregularity," International Journal of Civil Engineering and Technology (IJCIET) Vol. 7, 2016, pp. 257-264.

10. Shah Dhara and Shrivastava Anjuri, "Critical Analysis of Building with Vertical Irregularities as per IS 1893 part-1:2002," International Journal of Civil, Structural and Development Vol. 8, Issue 4, 2018, pp. 11-22.

11. Shelke R.N. and Ansari U.S., "seismic analysis of vertically irregular RC building frames," International Journal of Civil Engineering and Technology (IJCIET), Vol. 8, Issue 1, 2017, pp.155-169.

\section{AUTHORS PROFILE}

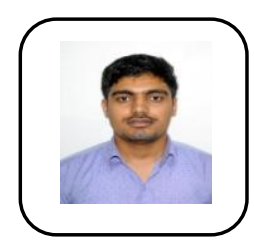

Krishna Prasad Bhatta, M.E. Structure, Civil Engineering Department, Chandigarh University, Gharuan, Mohali, Punjab, India received B.E. in Civil Engineering from NAST, Pokhara University, Nepal.

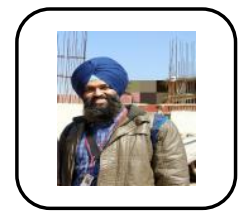

Gurpreet Singh, Assistance Professor, Civil Engineering Department, Chandigarh University, Gharuan, Mohali, Punjab, India. Received M.E. (structure) from Thapar University, Patiala, India in 2014. Research interest in Structural Engineering, Earthquake Engineering, Concrete Composite Structure and Dynamic Analysis of Frame. 